\title{
Micropropagation of Asparagus densiflorus via axillary shoots, indirect organogenesis and somatic embryogenesis
}

Anna Pindel

\author{
Unit of Botany and Plant Physiology \\ Institute of Plant Biology and Biotechnology \\ University of Agriculture in Kraków \\ 29 Listopada 54, 31-425 Kraków, Poland
}

\begin{abstract}
The present study has described a simple protocol for efficient plant regeneration of Asparagus densiflorus 'Sprengeri' and 'Myriocladus' using single-node spear explants, and indirect organogenesis via callogenesis induced on internode explants. The results showed that the genotypes 'Sprengeri' and 'Myriocladus' regenerated to complete plants via nodal cultures and callus tissue, but the plant regeneration response was higher in secondary explants on MS medium with NAA + kinetin $\left(1+1 \mathrm{mg} \mathrm{dm}^{-3}\right)$ after transfer onto a multiplication medium with IAA+BAP $\left(1+4 \mathrm{mg} \mathrm{dm}^{-3}\right)$, and then onto a rooting medium supplemented with IBA (10 mg $\left.\mathrm{dm}^{-3}\right)$ or NAA + kinetin $\left(1+1 \mathrm{mg} \mathrm{dm}^{-3}\right)$. Primary explants of both cultivars showed high regenerative potential (via the callus stage) on MS medium with IAA+BAP. The cultivar Sprengeri also regenerated via somatic embryogenesis. Both kinds of 'Meyeri' explants have a morphogenetic potential for the formation of shoots, which, however, were not capable of rooting. This confirms that the explant, genotype and culture medium are determining factors in the in vitro plant regeneration system.
\end{abstract}

Key words: ornamental asparagus, micropropagation, somatic embryogenesis

\section{Abbreviations:}

ABA - abscisic acid, BAP - 6-benzylaminopurine, GA - giberellic acid, IAA - indole-3-acetic acid, IBA - indole-3-butyric acid, NAA - $\alpha$-naphtaleneacetic acid, p-CPA - p-chlorophenoxyacetic acid, 2,4-D -2,4-dichlorophenoxyacetic acid

\section{INTRODUCTION}

Asparagus L. is the main genus of the Asparagaceae Juss. family (Kanno and Yokoyama 2011), and belongs to sclerophytes living in dry, warm or hot climates (from sub-frigid climates to the tropics) in native regions. They have developed various structural adaptations guarding against excessive water loss by transpiration. The cuticles over exposed surfaces are thick, sometimes becoming even thicker than the epidermal cells; stomata are often reduced in number. Plants have small, reduced leaves, and stems can also simulate leaves, being then referred to as cladodes. Cladodes are sometimes called phylloclades or cladophylls. Cladodes are stems of determinate growth, flattened and leaf-like. They are often produced in the axils of a true leaf, which may be reduced to a scale leaf. Asparagus cladodes comprise more than one internode (Cronk 2009). They have a hypodermis, the cells of which are thick-walled. The tip of an 
asparagus spear has three main components: shoot ground tissue, buds and bracts, all of which have some chloroplast-containing cells and vascular connections (King and Davis 1992).

Among the 300 or so species of the genus Asparagus, the A. officinalis L. is an important vegetable crop plant. Some asparagus species are utilized as ornamental plants, and A. racemosus is of medicinal importance. The very popular A. densiflorus (Kunth) Jessop and A. setaceus (Kunth) Jessop (common names: bushy asparagus, fern asparagus, sprengeri fern) are easy to grow, yet their propagation is difficult; vegetative (asexual) propagation by segmentation of the crown from mother clumps is limited because only a small number of plants can be obtained from a single crown during one season, and for this reason domesticated Asparagus germplasm is limited (Khandaka et al. 1996). This is confirmed by research carried out by Suranjana et al. (2010). The sowing of the seeds must be done soon after harvest, but the seed germination rate is rather low. Pindel (1997) developed a method in which the conditions of bird alimentary canal was simulated by soaking in water and in an $\mathrm{HCl}$ solution whose acidity was $\mathrm{pH}$ 3.0. Soaking the seeds of A. densiflorus 'Sprengeri' and A. densiflorus 'Meyeri' at a temperature of $25^{\circ} \mathrm{C}$ for 48 hours accelerated germination and the initial growth of seedlings but did not affect the germination percentage.

Difficulties in the reproduction of ornamental asparagus using either the sexual or asexual method mean that there is a need for a more sophisticated method of propagation, namely by tissue culture, which offers a potential for unlimited production of clones and gives the possibility to transfer into plants genes from any sources. Two methods have been widely tried for $A$. officinalis. In one of them, lateral buds excised from elongating spears were cultured and a new plant was obtained from each bud. In the other method, slices of internodes were stimulated to form callus, and subsequently plantlets were regenerated from the callus through indirect organogenesis or somatic embryogenesis (Reuther 1977, 1996, Shuxing et al. 1995). A. officinalis was the first plant among monocotyledonous plants to be regenerated from tissue culture (Wilmar and Hellendoorn 1968) and, as many researchers had reported before, these methods were applied in the breeding of new virus-free and resistant plants to Fusarium ssp. varieties (Kanno and Yokoyama 2011). Highly disease-resistant edible asparagus cultivars could be derived after protoplast fusion of the two ornamental cultivars of $A$. densiflorus, 'Sprengeri' and 'Meyeri', or wild A. macowanii (which has been classified as being immune to $F$. oxysporum f.sp. asparagi, $F$. moniliforme and Puccinia asparagi) by the introduction of foreign resistance genes into protoplasts of A. officinalis plasmid, or electroporation and selection of somaclonal variation (Dan and Stephens 1991, 1997, Kunitake and Mii 2001, Mukhopadhyay et al. 2002, Uragami 1995). Marcellan and Camadro (2000) tried to circumvent the pre- and post-zygotic hybridization barriers using in vitro embryo rescue cultures following A. officinalis $\times$ A. densiflorus crosses.

For these reasons, it is necessary to develop an efficient multiplication protocol for $A$. densiflorus. So far there have been only a few papers regarding efficient methods of micropropagation of A. densiflorus and on the introduction of genes of fungal disease resistance (Benmoussa et al. 1996, Pindel 2002, Pindel and Pindel 1995, 2001, Stephens et al. 1989, Toma and Rasheed 2012, 2013). The morphology and taxonomy of the genus Asparagus (belonging to the Monocotyledons group), and the xeromorphic habits are essential aspects to consider when selecting explants and in vitro methods. Phylogeny per se promotes recalcitrance problems. Monocotyledonous shoot meristems are basal in origin, and their vascular tissues lack cambium and meristematic cell types that are particularly responsive under cultivation conditions (Benson 2000).

This paper describes the application of various in vitro methods for the propagation of ornamental asparagus, with particular focus on the problems of obtaining the starting tissue to initiate cultures of three $A$. densiflorus cultivars.

\section{MATERIAL AND METHODS}

The experiments were carried out in the in vitro laboratory and greenhouse of the University of Agriculture in Kraków (Poland).

\section{Plant material}

The three cultivars of Asparagus densiflorus (Kunth) Jessop: Sprengeri, Meyeri and Myriocladus were used for experiments. The explants were taken from 2-3-year-old adult plants grown in a greenhouse - primary explants, and from juvenile plant material (seedlings) that was grown in vitro on the SSM medium (Tab. 1) - secondary explants. Two types of explants: single nodes and sections of internodes, of each source of 
Table 1. Composition of the media used in the different steps of in vitro propagation of $A$. densiflorus

\begin{tabular}{|c|c|c|c|c|}
\hline Function & & $\begin{array}{l}\text { Salts, vitamins } \\
\text { and sucrose } \\
\text { supplementation }\end{array}$ & Growth regulators & $\begin{array}{l}\text { Gelling } \\
\text { agent } \\
\% \mathrm{w} / \mathrm{v}\end{array}$ \\
\hline $\begin{array}{l}\text { Seed sowing } \\
\text { medium }\end{array}$ & SSM & $\begin{array}{l}1 / 2 \mathrm{LS}+2 \% \text { Suc } \\
\text { (without } \\
\text { vitamins) }\end{array}$ & none & $\begin{array}{l}\text { agar Difco } \\
0.6\end{array}$ \\
\hline \multirow{3}{*}{ Starting medium } & SM1 & $\mathrm{MS}+3 \% \mathrm{Suc}$ & biotin $\left(0.01 \mathrm{mg} \mathrm{dm}^{-3}\right)$, NAA $\left(1 \mathrm{mg} \mathrm{dm}^{-3}\right)$, kinetin $\left(1 \mathrm{mg} \mathrm{dm}^{-3}\right)$ & \multirow{3}{*}{$\begin{array}{l}\text { agar Difco } \\
0.8\end{array}$} \\
\hline & SM2 & $\mathrm{MS}+3 \% \mathrm{Suc}$ & glutamine (200 $\left.\mathrm{mg} \mathrm{dm}^{-3}\right)$, IAA $\left(1 \mathrm{mg} \mathrm{dm}^{-3}\right)$, BAP $\left(4 \mathrm{mg} \mathrm{dm}^{-3}\right)$ & \\
\hline & SM3 & $\mathrm{LS}+3 \% \mathrm{Suc}$ & gibberellic acid $\left(0.2 \mathrm{mg} \mathrm{dm}^{-3}\right)$, NAA $\left(1 \mathrm{mg} \mathrm{dm}^{-3}\right)$, kinetin $\left(1 \mathrm{mg} \mathrm{dm}^{-3}\right)$ & \\
\hline \multirow{3}{*}{$\begin{array}{l}\text { Multiplication } \\
\text { medium }\end{array}$} & MM1 & $\mathrm{MS}+3 \% \mathrm{Suc}$ & glutamine $\left(200 \mathrm{mg} \mathrm{dm}^{-3}\right)$, IAA $\left(1 \mathrm{mg} \mathrm{dm}^{-3}\right)$, BAP $\left(4 \mathrm{mg} \mathrm{dm}^{-3}\right)$ & \multirow{3}{*}{$\begin{array}{l}\text { agar Difco } \\
0.8\end{array}$} \\
\hline & MM2 & $\mathrm{MS}+6 \% \mathrm{Suc}$ & $\operatorname{IAA}\left(0.5 \mathrm{mg} \mathrm{dm}^{-3}\right), \operatorname{BAP}\left(1 \mathrm{mg} \mathrm{dm}^{-3}\right)$ & \\
\hline & MM3 & $\mathrm{LS}+3 \% \mathrm{Suc}$ & glutamine $\left(200 \mathrm{mg} \mathrm{dm}^{-3}\right)$, IAA $\left(1 \mathrm{mg} \mathrm{dm}^{-3}\right)$, BAP $\left(4 \mathrm{mg} \mathrm{dm}^{-3}\right)$ & \\
\hline \multirow{3}{*}{ Rooting medium } & RM1 & $\mathrm{MS}+3 \% \mathrm{Suc}$ & $\operatorname{IBA}\left(10 \mathrm{mg} \mathrm{dm}^{-3}\right)$ & \multirow{3}{*}{$\begin{array}{l}\text { agar Difco } \\
0.8\end{array}$} \\
\hline & RM2 & $\mathrm{MS}+6 \% \mathrm{Suc}$ & IAA $\left(0.5 \mathrm{mg} \mathrm{dm}^{-3}\right)$, BAP $\left(1 \mathrm{mg} \mathrm{dm}^{-3}\right)$ & \\
\hline & RM3 & $\mathrm{MS}+3 \% \mathrm{Suc}$ & $\begin{array}{l}\text { Ca D-pantothenic acid }\left(1 \mathrm{mg} \mathrm{dm}^{-3}\right) \text {, NAA }\left(1 \mathrm{mg} \mathrm{dm}^{-3}\right) \text {, kinetin } \\
\left(1 \mathrm{mg} \mathrm{dm}^{-3}\right)\end{array}$ & \\
\hline \multirow{5}{*}{$\begin{array}{l}\text { Callus induction } \\
\text { medium }\end{array}$} & CM1 & $\mathrm{MS}+3 \%$ Suc & IAA $\left(0.5 \mathrm{mg} \mathrm{dm}^{-3}\right)$, BAP $\left(1 \mathrm{mg} \mathrm{dm}^{-3}\right)$ & \multirow{3}{*}{$\begin{array}{l}\text { agar Difco } \\
0.8\end{array}$} \\
\hline & $\mathrm{CM} 2$ & $\mathrm{MS}+3 \% \mathrm{Suc}$ & NAA $\left(1 \mathrm{mg} \mathrm{dm}^{-3}\right)$, kinetin $\left(1 \mathrm{mg} \mathrm{dm}^{-3}\right)$ & \\
\hline & CM3 & $\mathrm{MS}+3 \% \mathrm{Suc}$ & $2,4-\mathrm{D}\left(1 \mathrm{mg} \mathrm{dm}^{-3}\right)$, kinetin $\left(1 \mathrm{mg} \mathrm{dm}^{-3}\right)$ & \\
\hline & CM4 & $\mathrm{MS}+3 \% \mathrm{Suc}$ & Dicamba $\left(10 \mathrm{mg} \mathrm{dm}^{-3}\right)$ & $\begin{array}{l}\text { Phytagel } \\
0.3\end{array}$ \\
\hline & CM5 & $\mathrm{MS}+3 \% \mathrm{Suc}$ & Picloram $\left(10 \mathrm{mg} \mathrm{dm}^{-3}\right)$ & $\begin{array}{l}\text { Phytagel } \\
0.3\end{array}$ \\
\hline \multirow{3}{*}{$\begin{array}{l}\text { Plant } \\
\text { regeneration } \\
\text { medium }\end{array}$} & PR1 & $\mathrm{MS}+3 \% \mathrm{Suc}$ & IAA $\left(1 \mathrm{mg} \mathrm{dm}^{-3}\right)$, BAP $\left(4 \mathrm{mg} \mathrm{dm}^{-3}\right)$ & \multirow{3}{*}{$\begin{array}{l}\text { agar Difco } \\
0.8\end{array}$} \\
\hline & PR2 & $\mathrm{MS}+3 \% \mathrm{Suc}$ & $\operatorname{IBA}\left(10 \mathrm{mg} \mathrm{dm}^{-3}\right)$ & \\
\hline & PR3 & $\mathrm{MS}+3 \%$ Suc & $\operatorname{IAA}\left(0.5 \mathrm{mg} \mathrm{dm}^{-3}\right), \operatorname{BAP}\left(1 \mathrm{mg} \mathrm{dm}^{-3}\right)$ & \\
\hline \multirow{2}{*}{$\begin{array}{l}\text { Embryo- } \\
\text { developing } \\
\text { medium }\end{array}$} & ED1 & $\mathrm{MS}+6 \% \mathrm{Suc}$ & $\begin{array}{l}\text { NAA }\left(0.1 \mathrm{mg} \mathrm{dm}^{-3}\right) \text {, zeatin }\left(0.2 \mathrm{mg} \mathrm{dm}^{-3}\right), \text { ABA }\left(0.05 \mathrm{mg} \mathrm{dm}^{-3}\right) \text {, } \\
\text { glycine }\left(75 \mathrm{mg} \mathrm{dm}^{-3}\right) \text {, glutamine }\left(800 \mathrm{mg} \mathrm{dm}^{-3}\right) \text {, casein hydrolysate } \\
\left(500 \mathrm{mg} \mathrm{dm}^{-3}\right)\end{array}$ & $\begin{array}{l}\text { Phytagel } \\
0.2\end{array}$ \\
\hline & ED2 & $\mathrm{UM}^{*}+3 \% \mathrm{Suc}$ & kinetin $\left(0.125 \mathrm{mg} \mathrm{dm}^{-3}\right)$ & liquid \\
\hline $\begin{array}{l}\text { Embryo } \\
\text { maturation } \\
\text { medium }\end{array}$ & EM & $\mathrm{MS}+4 \% \mathrm{Suc}$ & $\begin{array}{l}\text { NAA }\left(0.1 \mathrm{mg} \mathrm{dm}^{-3}\right) \text {, kinetin }\left(0.5 \mathrm{mg} \mathrm{dm}^{-3}\right) \text {, ancymidol }(0.75 \mathrm{mg} \\
\left.\mathrm{dm}^{-3}\right) \text {, glutamine }\left(800 \mathrm{mg} \mathrm{dm}^{-3}\right) \text {, casein hydrolysate }\left(500 \mathrm{mg} \mathrm{dm}^{-3}\right)\end{array}$ & $\begin{array}{l}\text { Phytagel } \\
0.3\end{array}$ \\
\hline \multirow{3}{*}{$\begin{array}{l}\text { Embryo } \\
\text { germination } \\
\text { medium }\end{array}$} & $\mathrm{R} 1$ & $\mathrm{MS}+3 \% \mathrm{Suc}$ & $\begin{array}{l}\text { NAA }\left(0.1 \mathrm{mg} \mathrm{dm}^{-3}\right) \text {, kinetin }\left(0.5 \mathrm{mg} \mathrm{dm}^{-3}\right) \text {, glutamine }\left(800 \mathrm{mg} \mathrm{dm}^{-3}\right) \text {, } \\
\text { casein hydrolysate }\left(500 \mathrm{mg} \mathrm{dm}{ }^{-3}\right)\end{array}$ & $\begin{array}{l}\text { Phytagel } \\
0.3\end{array}$ \\
\hline & $\mathrm{R} 2$ & $\mathrm{MS}+3 \% \mathrm{Suc}$ & $\begin{array}{l}\text { NAA }\left(0.1 \mathrm{mg} \mathrm{dm}^{-3}\right) \text {, kinetin }\left(0.5 \mathrm{mg} \mathrm{dm}^{-3}\right) \text {, ABA }\left(0.75 \mathrm{mg} \mathrm{dm}^{-3}\right) \text {, } \\
\text { glutamine }\left(800 \mathrm{mg} \mathrm{dm}^{-3}\right) \text {, casein hydrolysate }\left(500 \mathrm{mg} \mathrm{dm}^{-3}\right)\end{array}$ & $\begin{array}{l}\text { Phytagel } \\
0.3\end{array}$ \\
\hline & $\mathrm{R} 3$ & $\mathrm{MS}+6 \% \mathrm{Suc}$ & $\begin{array}{l}\text { NAA }\left(0.1 \mathrm{mg} \mathrm{dm}^{-3}\right) \text {, zeatin }\left(0.2 \mathrm{mg} \mathrm{dm}^{-3}\right), \text { ABA }\left(0.05 \mathrm{mg} \mathrm{dm}^{-3}\right) \text {, } \\
\text { glycine }\left(75 \mathrm{mg} \mathrm{dm}^{-3}\right) \text {, glutamine }\left(800 \mathrm{mg} \mathrm{dm}^{-3}\right) \text {, casein hydrolysate } \\
\left(500 \mathrm{mg} \mathrm{dm}^{-3}\right)\end{array}$ & $\begin{array}{l}\text { Phytagel } \\
0.2\end{array}$ \\
\hline
\end{tabular}

*UM medium - Uchimiya and Murashige (1974). The $\mathrm{pH}$ of the media was adjusted to 5.6 and they were autoclaved at $121^{\circ} \mathrm{C}$ for $20 \mathrm{~min}$. Twenty-five $\mathrm{ml}$ of each medium was dispensed aseptically into Erlenmeyer flasks

donor plants were used to initiate cultures through organogenesis, callus tissue, indirect organogenesis and embryogenesis.

\section{Nodal explant culture}

Six- to ten-cm-long young (not lignified) spears from greenhouse plants (Fig. 1a) were chosen and surface sterilized for $2 \mathrm{~min}$ in $70 \%(\mathrm{v} / \mathrm{v})$ ethyl alcohol, followed by immersion in $0.1 \%$ solution of mercuric chloride for $2 \mathrm{~min}$, and washed five times with sterile distilled water. Nodal segments from the middle zone of these spears and four- to six-week-old in vitro seedlings were aseptically excised transversally and used as explants for shoot initiation in both kinds of plant material (ex vivo and ex vitro).

The explants were placed horizontally in Erlenmyer flasks in contact with the starting medium (SM, Tab. 1) that was based on MS (Murashige and Skoog 1962) or LS (Linsmaier and 
Skoog 1965) medium with different combinations of growth regulators, under light conditions $\left(80 \mu \mathrm{mol} \mathrm{m} \mathrm{m}^{-2} \mathrm{~s}^{-1}\right.$ provided by a fluorescent light in a 16 -h photoperiod) at $23^{\circ} \mathrm{C}$. In order to determinate the regeneration efficiency, all nodal segments from one spear (both types, primary and secondary) were put into each flask. For each treatment, five replication were prepared-one replication consisted of four Erlenmayer flasks. New shoots (approx. 1.5 $-2.0 \mathrm{~cm}$ long) developed from the axillary buds were transferred onto a multiplication medium (MM - Tab. 1) after four weeks. Multiple, healthy shoots were excised and transferred onto the rooting medium (RM - Tab. 1) after the next 6 weeks. The final result of propagation by single-node explant cultures is expressed as per one starting explant that is, per one young spear of primary explants, or per one seedling (secondary explants).

\section{Callus induction}

The spear internodes from primary and secondary explants were cut into 1-2 mm-thick slices and used for callus induction. The segments were cultured on a callus induction medium (CM - Tab. 1) and incubated in darkness at $26^{\circ} \mathrm{C}$ for 12 weeks, and subcultured onto fresh media every 4 weeks.

\section{Indirect organogenesis}

The non-embryogenic tissue was carefully removed from the culture vessels after 12 weeks of subculture on CM media and the fresh weight was measured. Callus was then transferred onto a plant regeneration medium (RM - Tab. 1) supplemented with different combinations of growth regulators and organic compounds, and exposed to light. The frequency of rooted shoots (regenerated plantlets) was calculated after 18-20 weeks of culture (Tab. 3) - as in the single-node method.

\section{Indirect embryogenesis}

Embryogenic callus tissue, which formed preglobular stages, obtained on the CM4 and CM5 media with dicamba or picloram, and Phytage ${ }^{\mathrm{TM}}$ as gelling agent (Tab. 1), were weighed under sterile conditions and transferred onto solid or liquid embryo-developing media (ED). All the treatments were incubated under light conditions (16/8 $\mathrm{h}$ photoperiod, $50-60 \mu \mathrm{mol} \mathrm{m} \mathrm{m}^{-1} \mathrm{~s}^{-1}$ ), the liquid cultures with agitation at $90 \mathrm{rpm}$, and after 8 weeks the number of different embryonic stages was counted. The embryos developed on the ED media were transferred onto the EM medium for approx. 1 month, after which torpedo-shaped bipolar embryos were transferred onto the R media (Tab. 1).

\section{Acclimatization}

The in vitro regenerated plantlets with welldeveloped roots were washed under running water to remove the attached medium and transferred to pots containing a mixture of sphagnum peat moss and perlite (1:1), and maintained in a humid and shady environment. In the beginning, the plantlets were covered with a transparent polythene film; after 2 weeks the covers were removed and the plants were transferred to the greenhouse.

\section{Chromosome counting}

Root tips of asparagus seedlings (control) and randomly selected roots from each regeneration method were fixed in Carnoy's solution, hydrolyzed in $1 \mathrm{~N} \mathrm{HCl}$, and stained with $1 \%$ acetoorceine. Mitotic chromosomes at the metaphase plate were counted under a light microscope.

The comparison between means was carried out according to Duncan's multiple range test $(p<0.05)$.

\section{RESULTS AND DISCUSSION}

In the present investigation, two options were considered as the initial donor material: mature plants (primary explants) and juvenile tissue from seedlings (secondary explants), two kinds of explant (nodes and internodes), and three applications of clonal micropropagation (nodal explant culture, direct organogenesis, and embryogenesis).

\section{Nodal culture}

Only two cultivars, Sprengeri and Myriocladus, regenerated to complete plants. Table 2 summarizes the final results - the best combinations of media and their sequence in which the highest number of plants regenerated. The best results were obtained for ex vitro explants of $A$. densiflorus 'Sprengeri' and 'Myriocladus' -5.3 and 5.4 plantlets respectively (no significant difference), derived on MS medium supplemented with NAA, kinetin and biotin ('Sprengeri'), or BAP and glutamine ('Myriocladus'), multiplied on the same medium (Fig. 1b), and rooted on a medium supplemented with Calcium D-pantothenate, NAA and kinetin. When adult plants were used as the initial material, this method of micropropagation was less effective (Tab. 2).

Benmoussa et al. (1996) had observed a significant variation in the number of initiated shoot buds on different concentrations and combinations of NAA and BAP - the maximum number of shoots per explant (5.4) was initiated in 
Table 2. Effects of propagation of A. densiflorus 'Sprengeri', 'Meyeri' and 'Myriocladus' from single-node shoot segments

\begin{tabular}{|c|c|c|c|c|c|}
\hline \multirow{2}{*}{ Cultivar } & \multirow{2}{*}{ Explant } & \multicolumn{3}{|c|}{ Medium* } & \multirow{2}{*}{$\begin{array}{l}\text { Mean number of } \\
\text { regenerated plants }\end{array}$} \\
\hline & & Starting & Multiplication & Rooting & \\
\hline \multirow{2}{*}{ Sprengeri } & primary & SM1 & MM1 & RM1 & 1.0 a /one shoot ${ }^{* *}$ \\
\hline & secondary & SM1 & MM1 & RM1; RM3 & $5.3 \mathrm{~b} /$ one seed $\mathrm{d}^{* *}$ \\
\hline \multirow{2}{*}{ Meyeri } & primary & SM3 & MM3 & $\begin{array}{l}\text { RM1; RM2; RM3 also with } \\
\text { additions of } \mathrm{A} \text { and } \mathrm{Ph}^{* * *}\end{array}$ & $8.6 /$ one spear $^{* * * *}$ \\
\hline & secondary & SM3 & MM3 & $\begin{array}{l}\text { RM1; RM2; RM3 also with } \\
\text { additions of } \mathrm{A} \text { and } \mathrm{Ph}^{* * *}\end{array}$ & $6.7 /$ one seed ${ }^{* * * *}$ \\
\hline \multirow{2}{*}{ Myriocladus } & primary & SM2 & MM2 & RM2 & $3.3 \mathrm{c} /$ one spear \\
\hline & secondary & SM2 & MM1 & RM3 & $5.4 \mathrm{~b} /$ one seed \\
\hline
\end{tabular}

Means followed by the same letter do not differ significantly $(p<0.05) ; *$ for designations and composition, see Table $1 ;$ **seedling; $* * *$ with $\mathrm{A}$ - ancymidol $\left(0.75 \mathrm{mg} \mathrm{dm}^{-3}\right), \mathrm{Ph}-$ phloroglucinol $\left(162 \mathrm{mg} \mathrm{dm}^{-3}\right)$ and high concentration of sucrose $(6 \%) ; * * * *$ only shoots were obtained, but they were not capable of rooting

the presence of $0.4 \mu \mathrm{M}$ BAP and $5 \mu \mathrm{M}$ ancymidol, but these researchers did not obtain complete (rooted) plants. Dore (1988) had concluded that the behavior of asparagus in vitro was very similar to that of trees, because it is also a perennial crop whose juvenile tissues are the most responsive; however, the in vitro responses within a species and even among cultivars differed. For the genotype 'Meyeri', rhizogenesis was not observed (Pindel and Pindel 1995). For comparison, when Chin (1982) propagated A. officinalis by single-node spear segments, he obtained 4 to 7 rooted shoots, and Yang and Clore (1974) had obtained 2.6 shoots per explant, and only $35 \%$ of the shoots developed into complete plants. Lal et al. (2011), using the RAPD PCR technique for classifying asparagus varieties, found that $A$. densiflorus 'Sprengeri' and 'Meyeri' belonged to two different clusters, which indicates high genetic diversity between the two genotypes. According to Dan and Stephens (1997) and Pontaroli and Camadro (2005), A. officinalis is a diploid $(2 \mathrm{n}=2 \mathrm{x}=20)$, and according to Marcellan and Camadro (1996), A. densiflorus 'Sprengeri' is a hexaploid $(2 \mathrm{n}=6 \mathrm{x}=60)$, while 'Meyeri' is a tetraploid $(2 n=4 x=40)$.

\section{Callus induction}

Because of the simplicity of obtaining callus, the greatest number of in vitro experiments has been conducted with callus cultures. In the case of most plants, tissues of many organs are predisposed to cell division, but some organs are more predisposed than others. Generally, in monocotyledonous plants, callus can only be obtained from the tissue of certain organs. The cells of small pieces of explants on a growth-supporting medium become dedifferentiated and produce undifferentiated parenchyma cells. On the other hand, callus tissue is not uniform. The type of callus formed (friable, compact, different in colour and capability to regenerate new plants) depends upon the tissue from which it is derived and upon the constituents of the medium. Some workers have reported obtaining edible asparagus plants from callus

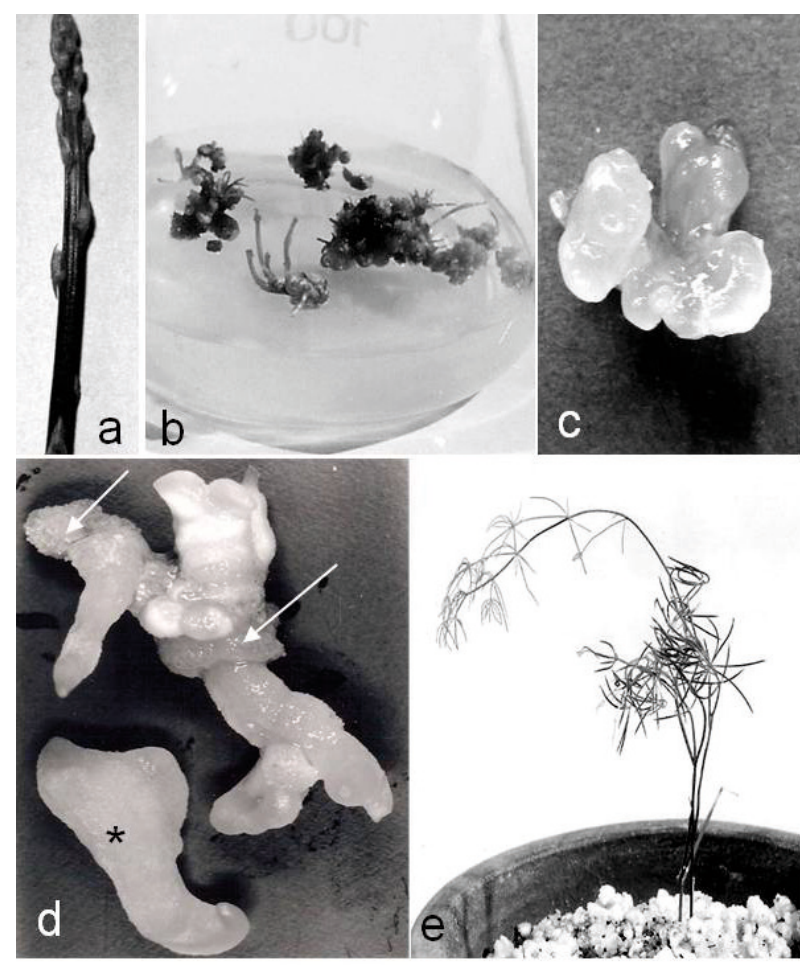

Figure 1. Young spear of asparagus used as a source of explants (a). Shoot induction from internode-derived callus of $A$. densiflorus 'Myriocladus' b). Organogenic callus of $A$. densiflorus 'Myriocladus' (c). Germinating embryos of $A$. densiflorus 'Sprengeri' with the base covered with embryogenic callus (arrow); abnormal somatic embryos (asterisk) (d). In vitro regenerated plant of A. densiflorus 'Sprengeri' during acclimatization 
Table 3. Effect of callus organogenesis in A. densiflorus 'Sprengeri', 'Meyeri' and 'Myriocladus'

\begin{tabular}{|c|c|c|c|c|c|}
\hline \multirow[b]{3}{*}{ Cultivar } & \multirow[b]{3}{*}{ Explant } & \multicolumn{2}{|c|}{ Medium* } & \multicolumn{2}{|c|}{ Results } \\
\hline & & \multirow[b]{2}{*}{$\begin{array}{c}\text { callus } \\
\text { initiation }\end{array}$} & \multirow[b]{2}{*}{$\begin{array}{l}\text { plantlet } \\
\text { regeneration }\end{array}$} & after 12 weeks & after $18-20$ weeks \\
\hline & & & & $\begin{array}{c}\text { mean weight of callus/ } \\
\text { explant } \\
\text { (mg) }\end{array}$ & $\begin{array}{l}\text { mean number } \\
\text { of regenerated } \\
\text { plantlets per each } \\
10 \mathrm{mg} \text { of callus }\end{array}$ \\
\hline \multirow{2}{*}{ Sprengeri } & primary & CM1 & PR1 & $50 \mathrm{a}$ & $4.8 \mathrm{a}$ \\
\hline & secondary & CM1 & PR2 & $60 \mathrm{~b}$ & $3.0 \mathrm{~b}$ \\
\hline \multirow{2}{*}{ Meyeri } & primary & CM2 & PR1, PR2, PR3** & $12 \mathrm{c}$ & - \\
\hline & secondary & CM3 & PR1, PR2, PR3** & $30 \mathrm{~d}$ & - \\
\hline \multirow{2}{*}{ Myriocladus } & primary & CM1 & PR3 & $55 \mathrm{a}$ & $0.9 \mathrm{c}$ \\
\hline & secondary & CM1 & PR3 & $62 \mathrm{~b}$ & $0.6 \mathrm{c}$ \\
\hline
\end{tabular}

Means in columns followed by the same letter do not differ significantly $(\mathrm{p}<0.05)$; for designations and composition, see Table 1 ;

** with ancymidol $\left(0.75 \mathrm{mg} \mathrm{dm}^{-3}\right)$, phloroglucinol $\left(162 \mathrm{mg} \mathrm{dm}^{-3}\right)$ and high concentration of sucrose $(6 \%)$

cultures when shoot segments were cultured on MS or LS media with NAA and kinetin. When the callus was subcultured on a medium with IAA and BAP, it became organogenic, and shoots, roots, or embryoids were obtained. Pant and Joshi (2009) concluded that NAA at various concentrations, either singly or in combinations, was effective in inducing callus, shoots and roots, which might be attributed to its chemical stability, low mobility in the plant and prolonged-action nature.

In the present study, based on earlier studies of the author, the media selected (respectively for the three tested genotypes) were those on which two types of tissue were formed: organogenic (Fig. 1c) and embryogenic (Fig. 1d) callus.

\section{Indirect organogenesis}

The presence of BAP was found to be essential for the development of adventitious buds. The best results were obtained using the combination of BAP with kinetin or NAA at 4 and $1 \mathrm{mg} \mathrm{dm}{ }^{-3}$ respectively. Morphogenic greenish, compact callus developed on the CM1, CM2 and CM3 media (Tab. 1). The strongest response was observed on the medium with IAA $(0.5 \mathrm{mg}$ $\left.\mathrm{dm}^{-3}\right)$ and BAP $\left(1.0 \mathrm{mg} \mathrm{dm}^{-3}\right)$ for ex vitro explants of A. densiflorus 'Sprengeri' and 'Myriocladus' (Tab. 3). Similar results had been reported by Pant and Joshi (2009), who observed shoot buds of A. racemosus on a medium supplemented with IAA and BAP. In my study, a less efficient callogenesis was observed for the cultivar Meyeri - only 2,4-D at $1.0 \mathrm{mg} \mathrm{dm}^{-3}$ and kinetin at $1.0 \mathrm{mg} \mathrm{dm}^{-3}$ induced cell divisions and the formation of small callus (Tab. 3). In contrast, rapidly growing nodular callus was observed on the medium containing dicamba (CM4) or picloram (CM5), and the callus grew faster than those induced in the presence of IAA + BAP, NAA + kinetin, or 2,4-D + kinetin (CM1-3) - Tab. 3. Different results had been reported by Benmoussa et al. (1996), who obtained the highest fresh weight of 'Sprengeri' callus on a medium with 2,4-D and kinetin, Dasgupta et al. (2007) observed the best response on MS medium supplemented with NAA+IAA+BA. In the work/experiments by Toma and Rasheed (2012), additions of both BAP and NAA gave the best callus regeneration ability in $A$. densiflorus.

Shoot formation from the surface of callus was observed after 3 months of culture. Among the various combinations and concentrations of growth regulators tested (data not presented), the maximum number of shoots per callus that regenerated to complete plants after the next 1.5 -2 months (without changing the medium) was obtained at a high BAP concentration (cytokinin to auxin ratio of $4: 1-$ Tab. 3). BAP is often used in woody plant cultures (Azad et al. 2005). Ex vivo derived 'Sprengeri' callus produced about 5 new plantlets from each $10 \mathrm{mg}$ of callus tissue, whereas ex vitro explants regenerated to complete plants when callus was transferred onto the medium with IBA at the high concentration of $10 \mathrm{mg} \mathrm{dm}^{-3}$ - Tab. 3. Low regeneration efficiency was observed for 'Myriocladus'. Like in the cultivar Sprengeri, the maximum number of regenerated plantlets was recorded on the media supplemented with BAP, but at a lower concentration $\left(1.0 \mathrm{mg} \mathrm{dm}^{-3}\right)$. 'Meyeri' explants, too, had a morphogenetic potential for callus formation and then shoot regeneration; however, the response was significantly lower. In spite of the different compositions of the media 
Table 4. Callus initiation and morphogenetic characteristics depending on the kind of explant (after 12 weeks of culture)

\begin{tabular}{lcccc}
\hline Cultivar & Explant & Medium & Callus phenotype & $\begin{array}{c}\text { Mean callus weight } \\
\text { per one Erlenmeyer } \\
\text { flask (mg) }\end{array}$ \\
\hline \multirow{2}{*}{ Sprengeri } & primary & MS + dicamba $10 \mathrm{mg} \mathrm{dm}^{-3}(\mathrm{CM} 4)$ & $\begin{array}{c}\text { nodular, greenish-white } \\
\text { small nodular, white to yellow }\end{array}$ & $504 \mathrm{a}$ \\
& secondary & $\mathrm{MS}+$ dicamba $10 \mathrm{mg} \mathrm{dm}^{-3}(\mathrm{CM} 4)$ & $585 \mathrm{~b}$ \\
\hline \multirow{2}{*}{ Meyeri } & primary & $\mathrm{MS}+$ picloram $10 \mathrm{mg} \mathrm{dm}^{-3}(\mathrm{CM} 5)$ & yellowish, fine granulated on surface & $71 \mathrm{c}$ \\
& secondary & $\mathrm{MS}+$ picloram $10 \mathrm{mg} \mathrm{dm}^{-3}(\mathrm{CM} 5)$ & light yellow, nodular & $39 \mathrm{~d}$ \\
\hline \multirow{2}{*}{ Myriocladus } & primary & $\mathrm{MS}+$ dicamba $10 \mathrm{mg} \mathrm{dm}^{-3}(\mathrm{CM} 4)$ & white yellow, fine-grained & $500 \mathrm{a}$ \\
& secondary & $\mathrm{MS}+$ dicamba $10 \mathrm{mg} \mathrm{dm}^{-3}(\mathrm{CM} 4)$ & yellow, nodular & $590 \mathrm{~b}$ \\
\hline
\end{tabular}

Means followed by the same letter do not differ significantly $(p<0.05)$; data represent mean value of five replications, each with 10 cultures

Table 5. Different stages of somatic embryos depending on the explant

\begin{tabular}{lccc}
\hline Cultivar & Explant & Stages of embryos & End result \\
\hline Sprengeri & $\begin{array}{c}\text { primary } \\
\text { secondary }\end{array}$ & $\begin{array}{c}\text { globular and heart-shaped } \\
\text { globular, heart-shaped and bipolar }\end{array}$ & $\begin{array}{c}\text { abnormal embryos without plumule (Fig. 1d) } \\
\text { regenerated plants }\end{array}$ \\
\hline \multirow{2}{*}{ Meyeri } & primary & $\begin{array}{c}\text { slow-growing hard nodular callus } \\
\text { slow-growing friable granulated } \\
\text { callus }\end{array}$ & $\begin{array}{c}\text { brown callus without embryo-like structures } \\
\text { yellow to brown callus without embryo-like } \\
\text { structures }\end{array}$ \\
\hline \multirow{2}{*}{ Myriocladus } & primary & globular and heart-shaped & abnormal with radicular pole \\
& secondary & globular and heart-shaped & abnormal with elongated radicle \\
\hline
\end{tabular}

and organic additives tested, rhizogenesis of 'Meyeri' shoots was not achieved. So far, there have been no reports on the successful rooting of 'Meyeri' shoots. After the acclimatization period, $100 \%$ of A. densiflorus 'Sprengeri' and $80 \%$ of A. densiflorus 'Myriocladus' plants were able to survive. According to other reports on asparagus micropropagation through callus organogenesis, about $70 \%$ (Kar and Sen 1985) to 90\% (Toma and Rasheed 2013) of plantlets survived.

\section{Indirect embryogenesis}

The ability to produce embryogenic calli is usually genotype-dependent, and various genotypes differ in the efficiency of embryo production and conversion into plants ( $\mathrm{Li}$ and Wolyn 1997). In monocots, the selection of appropriate explant material is more important than the plant genotype (Uma et al. 2012). In the present investigation, nodular embryogenic callus was obtained from both kinds of explant in all the genotypes of A. densiflorus on media containing $10 \mathrm{mg} \mathrm{dm}^{-3}$ dicamba (CM4) or picloram (CM5) (Tab. 4). The high level of these auxins stimulated cell divisions and the formation of globular structures. The embryogenic calli differed in appearance from the non-embryogenic ones, and their morphology depended on the kind of initial explants (Tab. 4).
Following the incubation period, the callus weight of 'Sprengeri' and 'Myriocladus' explants increased 10 -fold compared to organogenic calli (Tabs 3 and 4), although Dasgupta et al. (2007) had reported that the callus tissue of $A$. densiflorus 'Sprengeri' became embryogenic after being transferred to a 2,4-D-containing medium. It has been suggested that 2,4-D may play a key role in initiating embryogenesis, especially in monocot cultures. However, Kępczyńska et al. (2001) observed globular embryos on a medium with picloram, and Benmoussa et al. (1997) used BAP and p-CPA to induce and maintain callus cultures, but the calli grew faster than those induced in the presence of 2,4-D.

Although nodular callus was initiated for all the genotypes tested, stable induction of embryogenic tissue which developed globular, heart-shaped and bipolar embryos was observed only for ex vitro explants of the genotype 'Sprengeri' (Tab. 5, Fig. 1d) after transfer onto the embryo-developing solid (ED1) or liquid (ED2) media. These results are in agreement with those of the other authors working with monocot embryogenic cultures (Dasgupta et al. 2007). They had found that the elimination of auxin (especially 2,4-D) from the medium along with additions of a low level of 


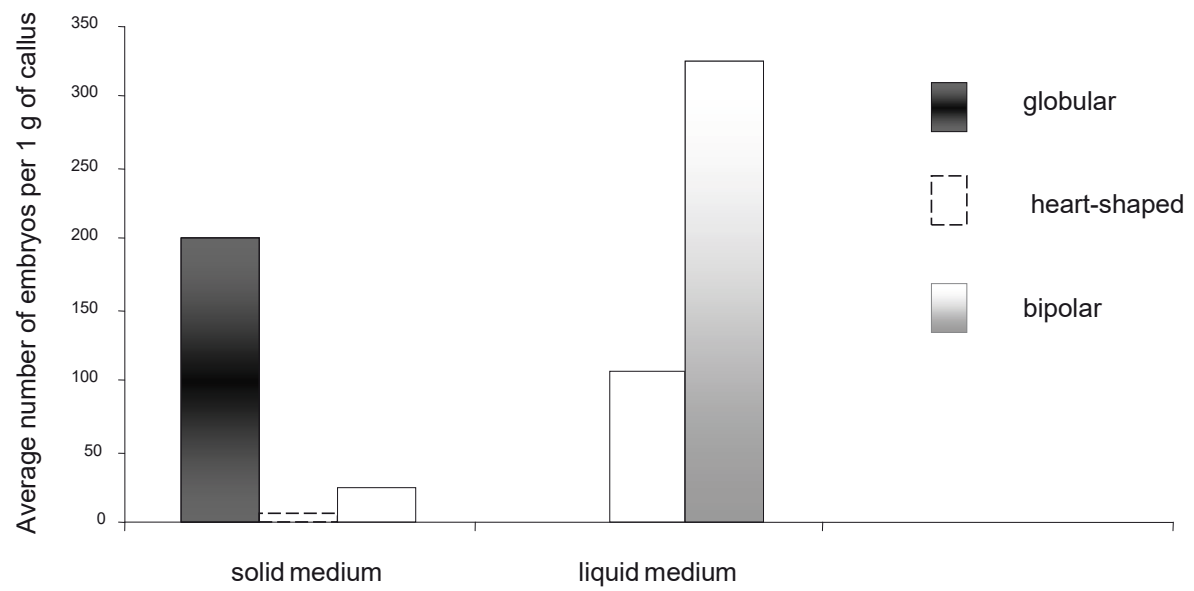

Figure 2. Different stages of $A$. densiflorus 'Sprengeri' somatic embryos per $1 \mathrm{~g}$ of callus

cytokinins promoted transition of globular embryos to the heart-shaped stages.

Figure 2 shows the average number of different stages of somatic embryos on the ED1 or ED2 media calculated after 2 months of culture. The greatest number of the bipolar stage was obtained in the liquid medium - 326 per $1 \mathrm{~g}$ of callus, compared with only 25 embryos per $1 \mathrm{~g}$ of callus tissue obtained on the solid medium. In A. densiflorus 'Myriocladus', formation of only globular and heart-shaped embryos was observed (Fig. 3).

Kępczyńska et al. (2001) had reported that only globular embryos of A. densiflorus 'Sprengeri' and $A$. plumosus were observed on a medium with picloram. Li and Wolyn $(1995,1997)$ had obtained 30-60 bipolar embryos and 98-143 globular embryos per $1 \mathrm{~g}$ of callus, depending on the genotype, for the edible asparagus. In Table 5, the final results obtained for calli of all the tested genotypes cultured on the embryo maturation (EM) medium are presented. One gram of callus was subsequently subcultured on the same fresh medium, and after

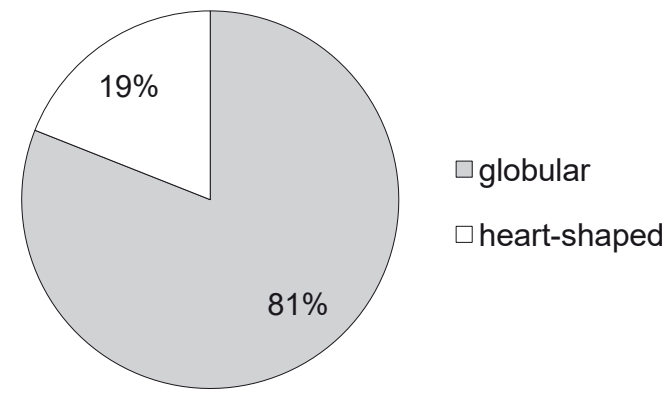

Figure 3. Percentages of different stages of somatic embryos of ex vitro explants of $A$. densiflorus 'Myriocladus' (the number of embryos obtained from $1 \mathrm{~g}$ of callus tissue $=100$ )
18 weeks of culture the results were recorded. The best results were achieved on the medium containing NAA, kinetin, glutamine, casein hydrolysate and ancymidol (data from other combinations are not included in this study), and $4 \%$ of sucrose. $\mathrm{Li}$ and Wolyn (1997) had reported that the use of a high sucrose level (4-10\%) followed by transfer onto the same medium with low carbohydrates $(2 \%)$ significantly increased embryo germination in A. officinalis. In the experiments presented here, the treatments with ancymidol $\left(0.75 \mathrm{mg} \mathrm{dm}^{-3}\right)$ and/ or ABA $\left(0.05 \mathrm{mg} \mathrm{dm}^{-3}\right)$ were the most effective for the production of bipolar embryos and conversion of embryos to plants. These results might have been a consequence of the activity of ancymidol, which reduced the levels of endogenous gibberellin, and ABA, which does not inhibit GA biosynthesis but counteracts its activity in somatic embryogenesis. Li and Wolyn (1995) had obtained 150 embryos per $1 \mathrm{~g}$ of callus and a $38 \%$ conversion rate on media supplemented with ancymidol or ABA (no statistical differences), while Kunitake et al. (1997) reported a $20-80 \%$ germination rate, depending on the source of carbohydrates, and Dasgupta et al. (2007) - 25 bipolar embryos per $1 \mathrm{~g}$ of tissue. According to most reports, many of the asparagus genotypes may be non-responsive to somatic embryogenesis. In this work, successful embryogenesis of asparagus was achieved only in the genotype 'Sprengeri' from ex vitro explants. For the other genotypes tested, abnormalities in morphology were observed. Although most 'Sprengeri' embryos developed in the liquid medium, regular conversion of embryos into plants occurred only on the solid medium. The percentage conversion of embryos into plantlets is presented in Fig. 4. 


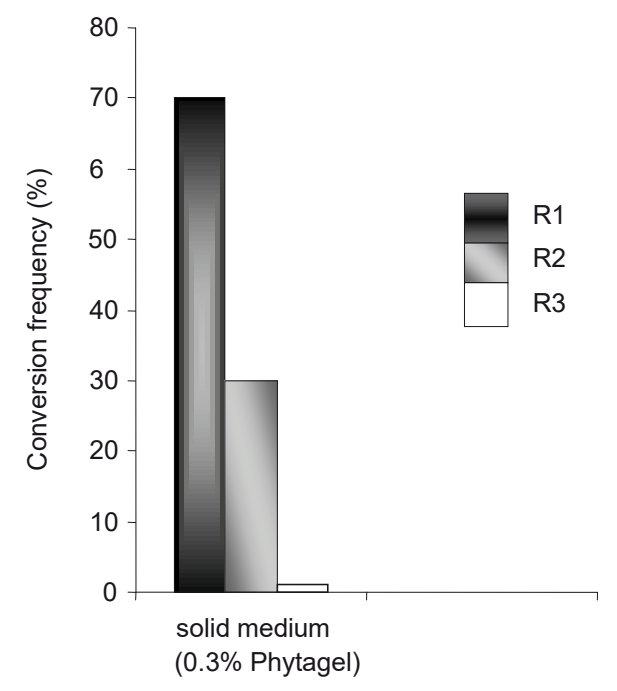

Figure 4. Conversion of torpedo-shaped somatic embryos of $A$. densiflorus 'Sprengeri' into plantlets

In general, the highest conversion rate (70\%) was achieved on the medium supplemented with NAA $\left(0.1 \mathrm{mg} \mathrm{dm}^{-3}\right)$ and kinetin $\left(0.5 \mathrm{mg} \mathrm{dm}^{-3}\right)$, glutamine $\left(800 \mathrm{mg} \mathrm{dm}^{-3}\right)$ and casein hydrolysate $(500 \mathrm{mg}$ $\mathrm{dm}^{-3}$ ), but pretreatment with ABA or ancymidol is required. The author's previous research (Pindel 2007) had shown that for ornamental asparagus the type of gelling agent is important. Normally developed embryos were obtained only on the Phytagel $^{\mathrm{TM}}$ solidified medium. These results are in agreement with the studies of Scholten and Pierik (1998), who found correlations between agar performance and plant species and regeneration processes. Prewein et al. (2004) demonstrated that the relationship between $\mathrm{ABA}$ and proline levels is modulated by the strength of the media gel. Welldeveloped plantlets were transferred to pots and all of them survived and acclimatized well under the greenhouse conditions. Dasgupta et al. (2007) reported that $80 \%$ of plantlets survived. A high survival percentage of asparagus plants produced in vitro is probably due to their structural adaptations to dry environment.

The in vitro regenerated asparagus plants did not differ in phenotype and chromosome number from the plants propagated by the traditional method (Fig. 1e). Metaphase plate analysis of root meristem cells revealed no changes in the number of chromosomes. All of the tested plants were $(2 n=$ $60)$ as donor plants.

\section{CONCLUSIONS}

In the present investigation, a protocol for the in vitro propagation of three cultivars of Asparagus densiflorus has been developed. Regeneration via somatic embryogenesis involving a callus phase would be suitable for most methods of genetic transformation in the breeding of new Fusariumresistant edible asparagus plants. Callus-born plants revealed unchanged phenotype and ploidy levels. Therefore, it is concluded that asparagus can be cloned by tissue culture.

\section{ACKNOWLEDGEMENT}

The author thanks Dr Barbara Nowak for her help in the finalization of the work.

\section{FUNDING}

The research was supported by the Polish Ministry of Science and Higher Education as part of the statutory activities of the Unit of Botany and Plant Physiology of the University of Agriculture in Kraków.

\section{CONFLICT OF INTEREST}

Author declares no conflict of interest.

\section{REFERENCES}

Azad M.A.K., Yokota S., OhKubo T.Y., ANDOH Y., Yahara S., Yoshizawa N., 2005. In vitro regeneration of the medicinal woody plant Phellodendron amurense Rupr. through excised leaves. Plant Cell Tissue Organ Cult. 80(1): 43-50.

Benmoussa M., Mukhopadhyay S., Desjardins Y., 1996. Optimization of callus culture and shoot multiplication of Asparagus densiflorus. Plant Cell Tissue Organ Cult. 47(1): 91-94.

Benmoussa M., Mukhopadhyay S., Desjardins Y., 1997. Factors influencing regeneration from protoplasts of Asparagus densiflorus cv. Sprengeri. Plant Cell Rep. 17(2): 123-128.

BENSON E.E., 2000. Special symposium: In vitro plant recalcitrance: An introduction. In Vitro Cell. Dev. Biol.-Plant 36(3): 141-148.

Chin C., 1982. Promotion of shoot and root formation in Asparagus in vitro by ancymidol. HortScience 17: 590-591.

Cronk Q.C.B., 2009. The Molecular Organography of Plants. Oxford University Press, Oxford, New York, USA.

DAN Y., StePhenS C.T., 1991. Studies of protoplast culture types and plant regeneration from callusderived protoplasts of Asparagus officinalis L. cv. Lucullus 234. Plant Cell Tissue Organ Cult. 27(3): 321-331.

DAN Y., STEPHens C.T., 1997. DNA polymorphism in somaclonal variants of Asparagus officinalis L. 
resistant to Fusarium oxysporum f. sp. asparagi. Plant Tissue Cult. Biotechnol. 3(2): 89-96.

Dasgupta C.N., Mukhopadhyay M.J., Mukhopadhyay S., 2007. Somatic embryogenesis in Asparagus densiflorus (Kunth) Jessop cv. Sprengeri. J. Plant Biochem. Biotechnol. 16(2): 145-149.

Dore C., 1988. Nouveau regard sur le comportement de l'asperge (Asparagus officinalis L.) multipliée in vitro. Agronomie 8: 843-850.

Kanno A., Yokoyama J., 2011. Asparagus. In: Wild Crop Relatives: Genomic and Breeding Resources, Vegetables. Kole C. (ed.), Springer-Verlag, Berlin, Heidelberg, 3: 23-42.

Kar D.K., Sen S., 1985. Propagation of Asparagus racemosus through tissue culture. Plant Cell Tissue Organ Cult. 5(1): 89-95.

KęPCZYŃSKA E., ZieliŃSKA S., KęPCZYŃSKi J., 2001. The effects of 2,4-D, NAA and picloram on callus induction and somatic embryogenesis in ornamental asparagus. Biotechnologia 2: 170-173.

Khandaka D.H., NeJidat A., Golan-Goldhirh A., 1996. Polymorphism and DNA markers for asparagus cultivars identified by random amplified polymorphic DNA. Euphytica 87(1): 39-44.

KING G.A., DAvis K.M., 1992. Identification, cDNA cloning, and analysis of mRNAs having altered expression in tips of harvested asparagus spears. Plant Physiol. 100(4): 1661-1669.

Kunitake H., Mir M., 2001. Somatic hybridization in Asparagus. In: Biotechnology in Agriculture and Forestry. Somatic Hybridization in Crop Improvement II. T. Nagata and Y.P.S. Bajaj (eds), Springer-Verlag, Berlin, Heidelberg, 49: 95-111.

Kunitake H., Nakashima T., Mori K., Tanaka M., 1997. Normalization of asparagus somatic embryogenesis using a maltose-containing medium. J. Plant Physiol. 150(4): 458-461.

Lal S., Mistry K.N., Vaidya P.B., Shah S.D., THAKer R.A., 2011. Genetic diversity among five economically important species of Asparagus collected from Central Gujarat (India) utilizing rapid markers (Random Amplification of Polymorphic DNA). Int. J. Adv. Biotechnol. Res. 2(4): 414-421.

Li B., Wolyn D.J., 1995. The effects of ancymidol, abscisic acid, uniconazole and paclobutrazol on somatic embryogenesis of asparagus. Plant Cell Rep. 14(8): 529-533.

Li B., WoLYN D.J., 1997. Interactions of ancymidol with sucrose and $\alpha$-naphthaleneacetic acid in promoting asparagus (Asparagus officinalis L.) somatic embryogenesis. Plant Cell Rep. 16: 879-883.

Linsmaier E.M., Skoog F., 1965. Organic growth factor requirements of tobacco cultures. Physiol. Plant. 18: 100-127.

Marcellan O.N., Camadro E.L., 1996. Self- and cross-incompatibility in Asparagus officinalis and Asparagus densiflorus cv. Sprangeri. Can. J. Bot. 74(10): 1621-1625.
Marcellan O.N., Camadro E.L., 2000. Preliminary results on embryo rescue for circumventing hybridization barriers in Asparagus. Biocell. 24(3): 247-251.

Mukhopadhyay S., Overney S., Yalle S., Desjardins Y., 2002. Regeneration of transgenic plants from electroporated protoplasts of Asparagus officinalis L. J. Plant Biochem. Biotechnol. 11(1): 57-60.

Murashige T., Skoog F., 1962. A revised medium for the rapid growth and bio assays with tobacco tissue cultures. Physiol. Plant. 15: 473-497.

Pant K.K., Joshi S.D., 2009. In vitro multiplication of wild Nepalese Asparagus racemosus through shoots and shoot induced callus cultures. Bot. Res. Int. 2(2): 88-93.

Pindel A., 2002. Studies of protoplast culture from callus of Asparagus densiflorus 'Sprengeri'. Folia Hort. 14(2): 243-250.

Pindel A., 2007. The effect of media hardness on the ornamental asparagus somatic embryos development. Zesz. Probl. Post. Nauk Roln. 523: 169-174.

Pindel A., Pindel Z., 1995. The comparison of micropropagation of Sprengeri and Meyeri cultivars of Asparagus densiflorus Jesson. Zesz. Nauk. Inst. Sad. Kwiac. 2: 101-106.

Pindel A., Pindel Z., 2001. Rhizogenesis of ornamental asparagus. Zesz. Nauk. AR w Krakowie 379: 139143.

Pindel Z., 1997. Effect of seeds treatment of two asparagus species [Asparagus densiflorus (Jesson) 'Meyeri', A. setaceus (Kunth) Jesson] on the germination and seedling growth. Zesz. Probl. Post. Nauk Roln. 449:145-152.

Pontaroli A.C., CAmadro E.L., 2005. Somaclonal variation in Asparagus officinalis plants regenerated by organogenesis from long-term callus cultures. Genet. Mol. Biol. 28(3): 423-430.

Prewein C., Wilhelm E., Vagner M., 2004. Water status and physiological parameters in relation to oak somatic embryo quality and germination ability. COST 843: 37-38.

Reuther G., 1977. Adventitious organ formation and somatic embryogenesis in callus of Asparagus and Iris and its possible application. Acta Hort. 78: 217 224.

ReUther G., 1996. Somatic embryogenesis in asparagus suspension cultures. Acta Hort. 415: 215-224.

Scholten H.J., Pierik R.L.M., 1998. Agar as gelling agent: Differential biological effects in vitro. Sci. Hort. 77: 109-116.

Shuxing S., Daoqian Z., Chenghe Z., Shixing L., 1995. Improved rate of callus and plantlet from anther culture of asparagus (Asparagus officinalis L.). Acta Hort. 402: 299-305.

Stephens C.T., De Vries R.M., Sink K.C., 1989. Evaluation of Asparagus species for resistance to Fusarium oxysporum f. sp. asparagii and F. moniliforme. HortScience: 24: 365-358. 
Suranjana R., Mukhopadhyay M.J., Mukhopadhyay S., 2010. Phylogenetic relationship among six economically important species of Asparagus utilizing RAPD, ISSR and isozyme polymorohism. Biores. Bull. 1(3): 157-164.

TOMA R.S., RASHEED K.A., 2012. In vitro propagation through seed culture and regeneration of Asparagus densiflorus L. through callus cultures derived from hypocotyls. Int. J. Pure Appl. Sci. Technol. 9(2): 94102.

Toma R.S., Rasheed K.A., 2013. The response of Asparagus densiflorus L. in vitro propagation to different potassium and ammonium nitrate levels in culture media. Int. J. Pure Appl. Sci. Technol. 17(2): 21-27.

Uchimiya H., Murashige T., 1974. Evaluation of parameters in the isolation of viable protoplasts from cultured tobacco cells. Plant Physiol. 54(6): 936-944.
Uma S., LaKshimi S., SARaswathi M.S., AKbar A., 2012. Plant regeneration through somatic embryogenesis from immature and mature zygotic embryos of Musa acuminata ssp. burmannica. In Vitro Cell. Dev. Biol.-Plant 48(5): 539-545.

Uragami A., 1995. Cryopreservation of Asparagus. In: Biotechnology in Agriculture and Forestry. Y.P.S. Bajaj (ed.), Springer-Verlag, Berlin, Heidelberg, 32: 332-344.

Wilmar C., Hellendroon M., 1968. Growth and morphogenesis of Asparagus cell cultured in vitro. Nature 217: 369-370.

YANG H.J., Clore W.J., 1974. Development of complete plantlets from moderately vigorous shoots of stock plants of asparagus in vitro. HortScience 9: 138-140.

Received April 11, 2017; accepted July 19, 2017 